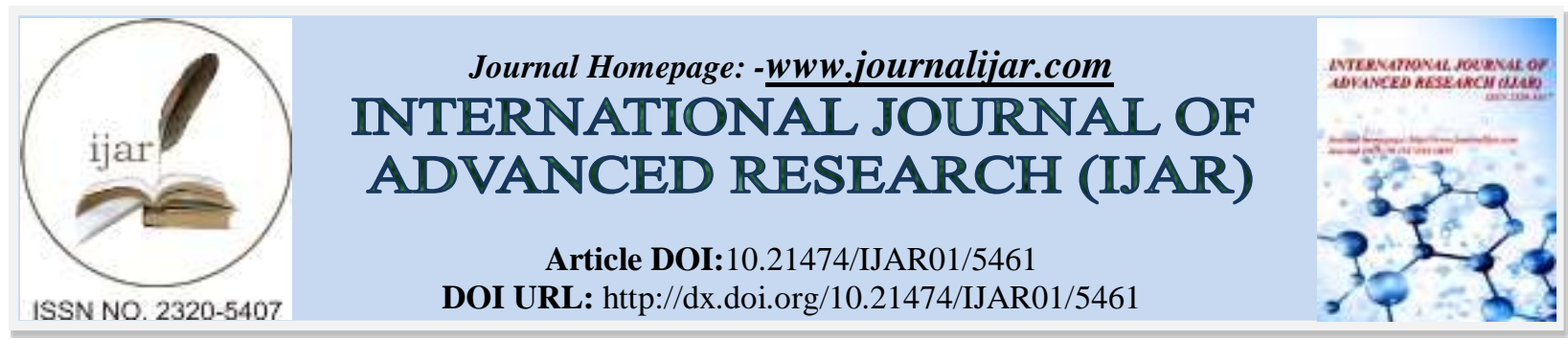

RESEARCH ARTICLE

\title{
DISTRIBUTION OF USE OF SPACES IN THE COASTAL OF FISHING VILLAGE BELAWAN MEDAN, INDONESIA.
}

\author{
B O Y Marpaung ${ }^{1}$ and Mutiara Widyasari². \\ Universitas Sumatera Utara.
}

\section{Manuscript Info}

Manuscript History

Received: 18 July 2017

Final Accepted: 20 August 2017

Published: September 2017

Key words:-

Social, economy, use space, settlement.

\section{Abstract}

Fishing Village Belawan Medan is one of the unplanned settlements located in the coastal area of Medan City, Indonesia. Social life (activities and behavior) has an influence on the distribution of space usage in these settlements. This can be seen from the uneven function of the use of space and facilities owned in this settlement. In addition, economic life also has an influence on the distribution of space usage. This is evidenced by the low economic community in this settlement. The purpose of this study is to analyze the distribution of spatial use that occurred in unplanned settlements. Also, it aims to find the impact of socio-economic life on the distribution and spread of space use in the region. The data were collected by observation (direct observation) and distributing questionnaires to the community living in Fishing Village Belawan. In addition, the research is also reinforced by the theory that has a link between the influence of socio-economic life with the distribution of space usage. The results of this study indicate that the socio-economic activities conducted simultaneously will make a spot location to be crowded. As with the existence of a little market which became an area where the community gathering settlement Fishing Village Belawan Medan.

Copy Right, IJAR, 2017,. All rights reserved.

\section{Introduction:-}

The coastal zone is an area that becomes the boundary between land (surface) with the ocean. Coastal areas are identical to floods due to rising sea levels. This is stated by The Federal Emergency Management Agency that the coastal has a zone $\mathrm{V}$ (speed zone) which is an area often affected by floods due to high tide. In fact, the government established between land and sea has a distance of about 12 miles to not build any buildings in the region. The informal settlements will occupy an area that has been exploited, such as land owned by the government and others (Hurskeinen, 2004). This fisherman's settlement stands on the land owned by PT. Pelindo. Fishing Village Belawan can be classified unplanned settlements because people living in this area do not have legitimate land titles. In addition, the public facilities contained in these settlements are still very minimal, both in the provision and management. It will have an effect on the social activities of the community. In addition to community factors (lack of land certificates, low education and lack of public facilities), there are also natural factors that affect the social life of the community. Sea tide is a natural disaster that often occurs in coastal areas. This natural factor indirectly has an influence on social life in society. In addition to social life, people in these settlements also have problems with their economies. People who work as fishermen are considered more backward than other professions. This is because the fisherman's economy depends heavily on the catch. This is what the fishermen think, especially the community of 
Fishing Village Belawan to find alternative other professions that can help their economy, one of them by opening a stall. The distribution of stalls in these settlements is uneven, affecting the distribution of land use. Due to the uneven distribution of food stalls in this settlement cause a phenomenon where between stalls with each other has a distance of only about five meters.

\section{Discussion:-}

Social life has a link with the activities and behavior of the community. Social activities undertaken by the community vary. Some community activities are based on gender. Men work as fishermen because this profession is classified as hard and rough. Meanwhile, most of the women work as housewives. Women have responsibility for their activities, such as cooking, taking care of children and households (Jeyarajah, 2015). Women have great power, control, and influence in their household. In the family, women have a large role, such as taking care of children, cooking up to prepare all the needs of the household. It is the responsibility of a married woman. Not only families, women also have control and even influence in a community environment. Women also have post-harvest responsibilities (Matthews, 2012). Women have influence in society especially when there is post-harvest activity. Post-harvest are activities undertaken by women after the fishermen return from the sea. This activity includes the processing of fish, carry out traditions and other social activities. Implementation of tradition is an activity undertaken by society together and regardless of gender. In carrying out the tradition, the community (various gender and age) participated and mingled with each other at this event.

In addition to differences in activities undertaken by the community based on gender, there is also a degree of community in the family associated with the social life of its inhabitants such as husband, wife and also children. The degree of a person in the family has an important influence on community activities and activities. For example, a family head generally works as a fisherman. The activities of fishermen have a relationship with matters relating to fishing, and ship repair (Setioko et al., 2011). This is a routine activity done by the fishermen before and after going home to the sea. In addition to activities carried out by the head of the family (fishermen), wife and children also have activities that they do respectively. Wives have activities related to their homes as well as their living environment, whereas children have related activities in helping their parents, such as repairing nets, ships and also participating in an activity in their neighborhood.

Not only gender and also the degree of society in the family, the existence of external factors also affect the social life of the community. External factors are rising sea water to the mainland or the tide. The rise of sea water caused by the attraction of the sun to the earth causing water to rise and flood the settlements of society (Franco, 1966). Communities whose homes are submerged in floods will conduct refugee activities. This is done because the flow of water that goes up to the settlement is quite high. This refugee activity needs help among the community (teamwork).

Most of the people living in coastal areas have professions as fishermen. This profession requires people to work hard because their economies depend heavily on catches. Fishermen are the most widely practiced professions of people living in the coastal areas (Ahmed et al., 2013). Fisherman's own profession is divided into three categories, namely professional fishermen, subsistence and seasonal. The difference between these three categories is only in the duration of fishing time by fishermen. Professional fishermen regularly and periodically catch fish, seasonal fishermen, only a few times a year, while subsistence fishermen catch fish only consumed by fishermen and their families (not selling fish catch). However, not all communities living in the coastal areas work as fishermen. This profession is generally only done by men only. People who do not work as fishermen will find other jobs

Other work done by communities in coastal areas is the trade. It has a relationship with the profession of fishermen. The merchant will sell fish obtained by fishermen in a Fish Auction Place. People who sell here are the residents who live in coastal areas. Seasonal fishermen catch fish only several times a year (Ahmed et al., 2013). The empty time they have (when not in the sea) is used to work with different professions. Some of them work as traders, pedicab drivers to workers. People choose to work as pedicab drivers and laborers, generally based on the economy they have. The economy of the fisherman is very dependent on nature and the weather. If the weather is not stable then most likely the public will earn quite a bit of income. Unlike the laborers, this profession has a steady income without knowing the state of nature and also the weather. In addition to pedicab drivers and laborers, the community also works as an entrepreneur. The entrepreneur's profession is generally done as a trader with a shop. 
Land use in coastal areas varies greatly. The use of land in coastal areas is generally dominated by residential functions. In addition to residential functions, there is also open space and facilities that function to support the needs of the community. Open space, hall to market is an area that is protected in a settlement (Garlake, 2002). The area is protected by a settlement because the location of the facility is located in the middle of the community settlement so it has a purpose to facilitate the community in accessing it, whether used as a social or economic activity. In addition to open space, hall to market available in coastal areas, there are also facilities for worship in a settlement. This facility of worship itself is used by the community in accordance with their respective religions. The daily life of society is never far from religious. Majority societies (especially Muslims) will worship every day. This is what makes the house of worship has the power to be used everyday society. There is no special provision in establishing a house of worship. But in its construction, the house of worship should have the accessibility that is easy to reach and adjust to the capacity of the number of people who come. If the capacity of the worship house cannot accommodate the existing community, the people will build a similar house of worship but different location. This is why many houses of worship spread in the same area.

In contrast to houses of worship that do not have provisions for establishing the location, office facilities have a specific location in the placement. The use of land that is functioned as an office area will be affected by the global configuration (Yang T, 2015). The global configuration itself is a position placement where one function of space can be accessed by the community, both people living in the area around and outside the settlement.

The social and economic life carried out by the community indirectly, has an influence on the distribution of space usage. People who live in urban areas generally use land, road networks and public facilities have the function and purpose as things that can maximize individual income (Hao et al., 2011). In informal settlements, the spread of land use is not managed optimally by the government, resulting in uneven distribution of spatial use in an area, especially coastal areas. The facility has a function to connect to activities undertaken by the community with the use of land (Setioko et al., 2011). Society has a variety of activities. People who often use one facility have the impact of the emergence of crowds in the location. For example, the place of fish auctions, markets, and docks. The location is often used by the community, especially fishermen to conduct transactions. This location (facility) is a liaison between community activities with land use, thus causing a crowd in an area.

The market is a fairly busy location in this area. This location is used by the community to sell their catch. Not only by fishermen, this location is also used by the community to trade and also buying and selling activities. Visitors who come to the location (where fish and market auctions) are not only people around the location but also from outside the region. In addition, the same thing happens in locations that serve as schools. Schools are linked to the occurrence of social and economic activities simultaneously. Of course, these activities involve students, teachers, and traders who sell nearby. Not only the school, the existence of the inhabitants who set up shop also make the area becomes crowded. Communities that have stalls generally provide chairs and tables as well as facilities for residents who want to come. This is what causes the location of the stall to be crowded even become the cause of the crowd in a settlement.

\section{Result:-}

The results examined by the researchers will be discussed and consists of 4 sub-chapters of research:

\section{Social Life of the Community in Fishermen Village Belawan Medan, Indonesia}

Activities are one part of the social life of the community. Activities that people do vary greatly. Activities undertaken by the community are influenced by gender. Society has its own role in doing its activities, but cannot be separated from a tradition. Tradition in this settlement is done by all gender so that society participate in the event (69.30\%). Tradition conducted in Fishing Village Belawan is an activity in giving thanks for the abundance of sustenance provided by God Almighty (Fig 1). 


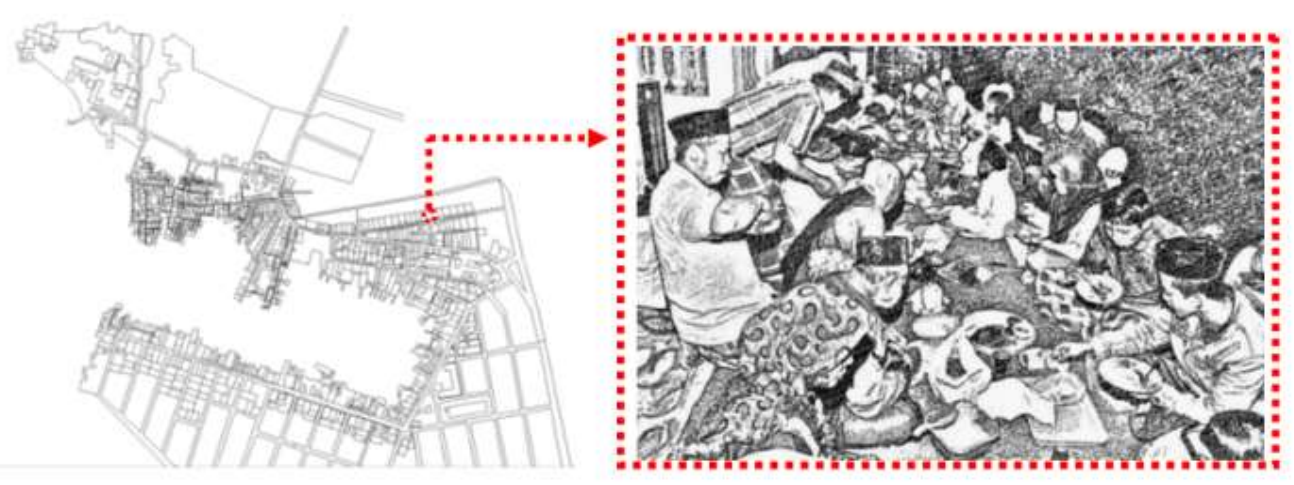

Key Map

Fig 1:- Illustration of Mapping of Traditional Implementation in Fishing Village Belawan

The implementation of this tradition uses the community house as the location to carry out this event (33.66\%). However, not all community homes can be used as a place to do this event. Only houses that can accommodate many visitors who used the community (34.65\%). Not only that, the houses that also have a strategic location are also used by the community in implementing this tradition. It aims to get people to easily access the location. The implementation of tradition is done by the community with all gender. A theory from Matthews (2012) which states that women have responsibilities made after the harvest. Post-harvest activities are activities undertaken after the fishermen return from the sea, such as processing fish and also carry out the tradition. This is what demands women get involved in the event tradition.

In addition to traditional events, residents of Fishing Village Belawan also perform a party event that is part of the social life of the community. The event that people often do in this settlement is the wedding party (75.24\%). In performing a party event will certainly use a space (Fig 2). Space used by the community is their home page (37.62\%). This is because of the sense of happiness felt by the community when carrying out a party in front of his house. In addition to the home page, the use of the road as a space for party execution is also often used by the community. Communities that run the party will generally close the access (road) that will be used by other residents. This, of course, gives a sense of discomfort to other road users. The purpose of the community in choosing the location of the party is to provide easy access for the guests who will come.

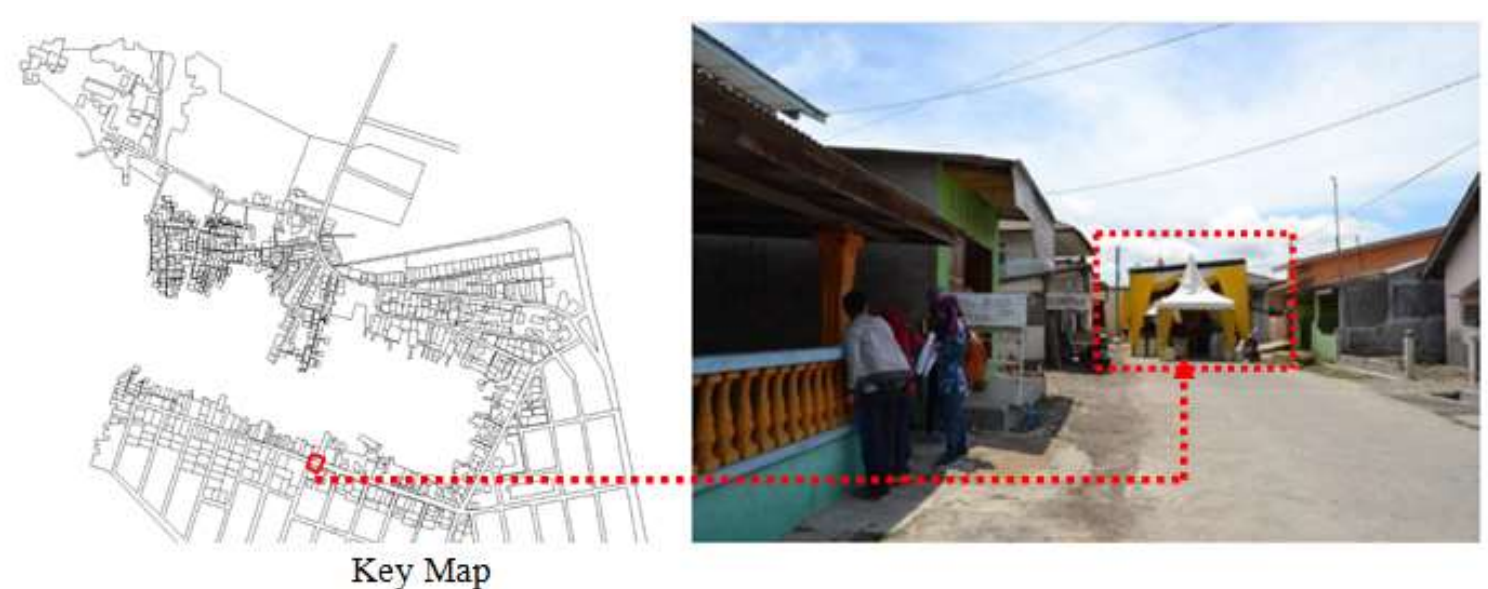

Fig 2:- Atmosphere of Party Implementation at Fishing Village Belawan

In carrying out the event, the community is required to participate in the event. The fishermen family helped fishermen and also socialize with the people who live in their home environment (Setioko et al., 2011). This causes the community with a variety of gender also work together in carrying out the party. Women generally do activities 
such as cooking to set the design. While men generally do activities such as maintaining security and attributes of the party.

In addition to environmental factors, there are natural factors that affect the social life of the community, one of which is the rise of sea water (Fig 3). The coastal area is identical with the rising tide (85.14\%). The impact felt by the people living in the Fishing Village Belawan settlement is the flood that inundated their homes. However, this rising flood will recede on its own within the space of three hours.

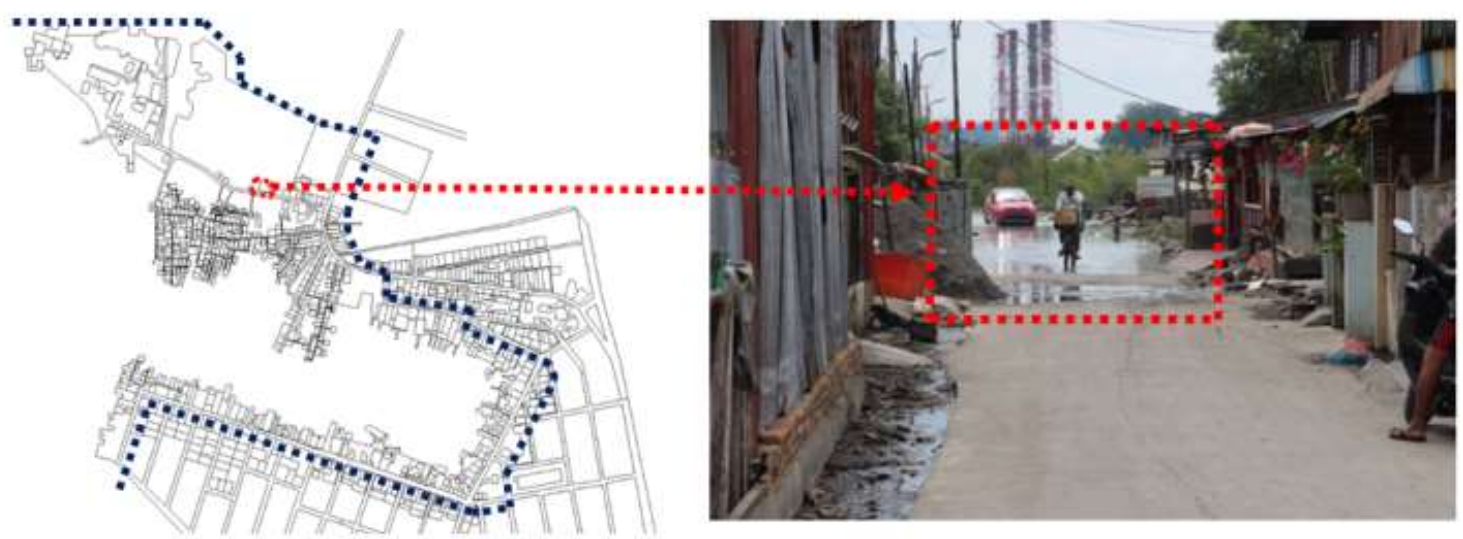

Key Map

Fig 3:- Atmosphere When Happened Increase of Water Install in Fishing Village Belawan

The occurrence of tidal sea water due to the attraction between the moon and the sun against the earth and routinely occur in coastal areas (Franco, 1966). This is what causes the government to not build any buildings in coastal areas (especially areas that jut into the sea). However, people living in Fishing Village Belawan are reluctant to move to other areas (31.68\%). This is because of the sense of comfort felt by the community considering the thick culture of teamwork still done by the inhabitants of Fishing Village Belawan Medan. Activities undertaken by the community when their houses are submerged in tidal water are kept at home (63.36\%). This is because of the sense to keep their valuables. However, people will also be displaced in the event of a high tide rising with high discharge.

\section{Economic Life of Society in Fishing Village Belawan Medan, Indonesia}

Most of the people living in the coastal areas have a profession as fishermen. However, people living in the Fishing Village Belawan of Medan chose not to work as fishermen (58.42\%). This is due to certain demands and hard work as fishermen. In addition, the fishermen's economy depends on the catch they get (Fig 4). Nevertheless, people continue to work with a variety of professions.

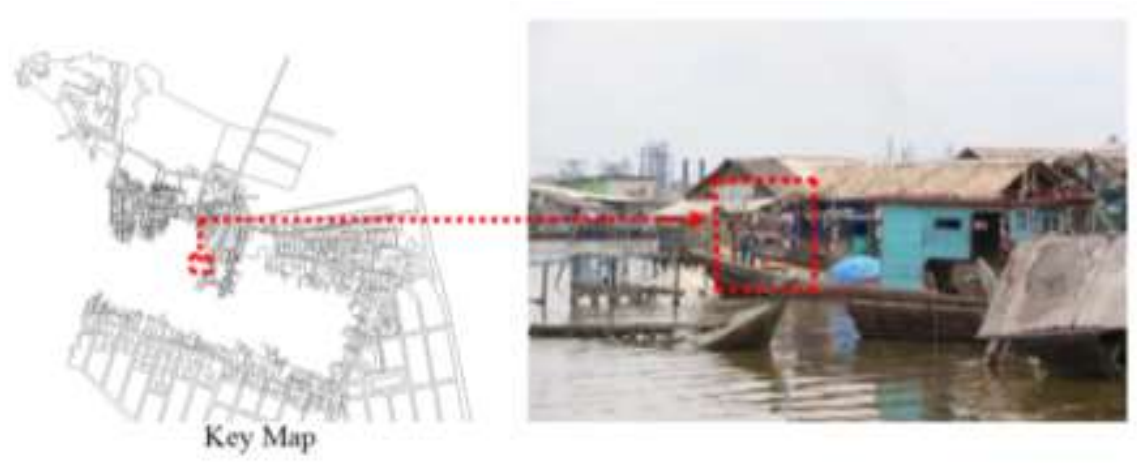

Fig 4:- Fishermen Improving Ships 
The fishing profession is divided into three categories, namely professional fishermen, subsistence and seasonal (Ahmed et al., 2013). The difference between these three fishermen is (1) professional fishermen catch fish regularly; (2) seasonal fishermen catch fish several times a year; and (3) subsistence fishermen catch fish only for their own consumption. The catches that fishermen can usually be immediately sold or reprocessed. People living in Fishing Village Belawan have very little fish cultivation (55.44\%). The public will generally sell directly. This is because in processing the fish, the community needs a large enough land to dry the processed products. Women have a post-harvest responsibility (Matthews, 2012). Post-harvest activities are activities undertaken by women after fishermen (men) return from the sea, such as fish processing and implement a tradition. People living in this region are very few who can process fish. Limited land becomes one of the problems that people have in this settlement. In addition, fish processing by drying also has its own risk. For example the existence of interference from children, even the weather is uncertain. In addition, the lack of skills possessed also become an obstacle experienced by the community in conducting the process of fish management.

In addition to processing fish and fishermen, the profession that people do to meet their economic needs is to work as an entrepreneur. One of the alternative jobs that people do is to set up a shop (54.45\%). This work is generally done by women living in these settlements. This is because women are related to domestic work. Women can take care of their housework (such as washing, cooking and taking care of the child) at the same time by opening a stall. The terrace of the house became the location of the establishment of a shop in the settlement (35.64\%). The terrace of the house is a fairly efficient location in the establishment of a shop (Fig 5). This is because there is no quotation of rent for the establishment of a stall. In addition, the terrace of the house also makes it easier for the owner of the shop in the supervision of its own shop (27.72\%). The community that owns the shop generally provides chairs and tables $(50.49 \%)$. These chairs and tables serve as a resting place as well as gathering with the community. The reason that the thought of the shop owner is that many people who come even a friend to chat. But the main purpose of the stall owners to provide chairs and tables is to give a busy impression on the stalls (19.80\%)

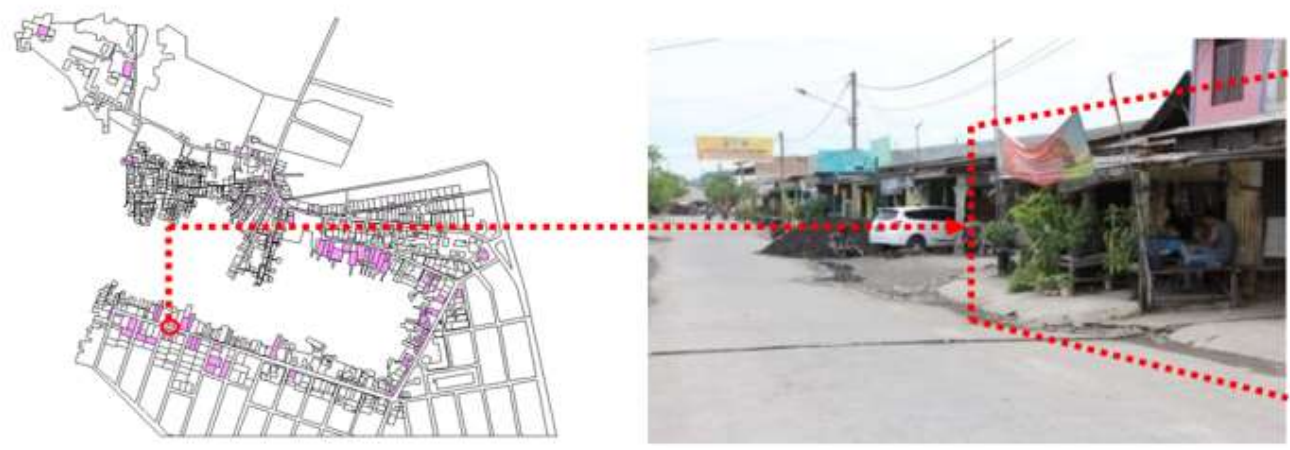

Key Map

Fig 5:- Atmosphere of Little Market in Fishing Village Belawan

The number of stalls available in the Fishing Village Belawan of Medan proves that coastal communities work as entrepreneurs more by opening stalls. Indirectly, stalls become a space that most of the people in the region use. Humans and their communities have a link in shaping the whole (comprehensive) space because different needs make the room complete (Rivlin, 1987). This is seen in the stalls that provide chairs and tables. Communities in these settlements often do gathering activities so as to make a space use happen in this area. Use of the space is a shop with the provision of chairs and tables that became the location of the gathering community. In addition, the community gathered in the stall certainly has links with economic activities so indirectly gathered activities will affect the economy of the community.

\section{Land Use in Fishing Village Belawan Medan, Indonesia}

Fishing Village Belawan Medan has a fairly varied land usage. Most of the use of space functioned as a dwelling. In addition to residential functions, some facilities sufficiently crowded the use of land in these settlements, such as the open space, religious facilities to offices (Fig 6). 


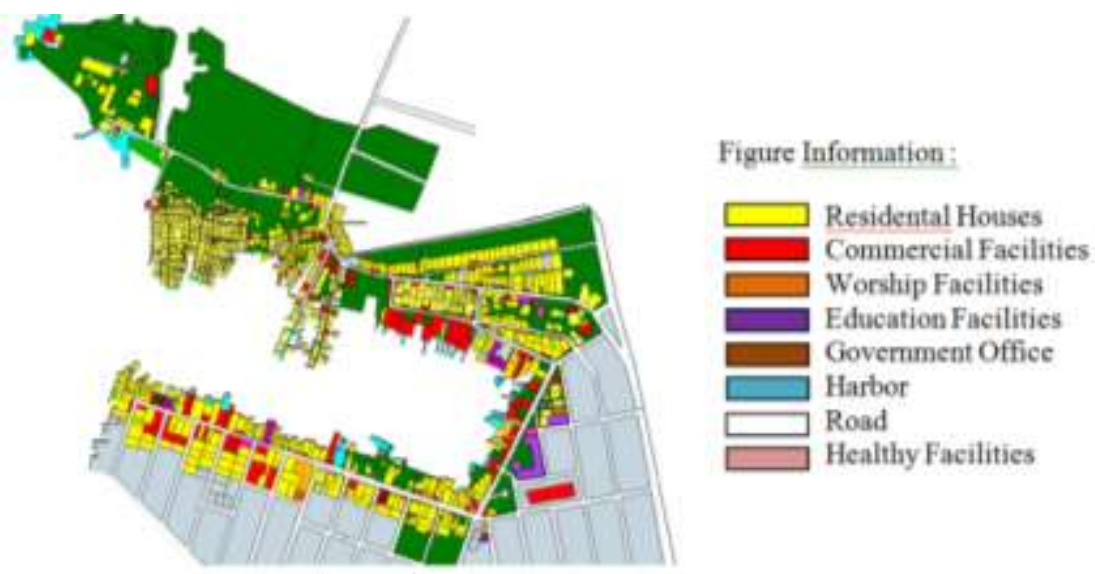

Fig 6:- Land Use Map in Fishing Village Belawan

Fishing Village Belawan Medan has quite a lot of open space (58.41\%). Open space in this settlement has a variety of functions, depending on the needs of its inhabitants. However, some open spaces are not used socially as they should. Open space that should be functioned as a space for children's playground, it is used as a garbage gathering area. This is quite unfortunate given the unavailability of playroom for children. Besides being used as a gathering place for garbage, available open space is also used in accordance with the needs of the community (36.63\%). This is visible when the time leading up to Independence Day and Eid al-Adha Day, open space is used as an area to race and also become the location of animal slaughter. Open space is protected by settlements. It has a goal to keep people living near the open space easily access the site (Garlake, 2002). In addition, to facilitate the community to be a positive thing, there are also negative impacts due to the placement of the space. Open space in the middle of the settlement is very easily accessible to the community so that people passing by can easily throw garbage in the area.

In addition to open space, there is also a house of worship that became one of space and land use in this settlement (Fig 7). Mosque and also the church is a house of worship that dominates in Fishing Village Belawan Medan. Placement of facilities of houses of worship is selected by the community with a strategic location so as to facilitate the community in accessing it.

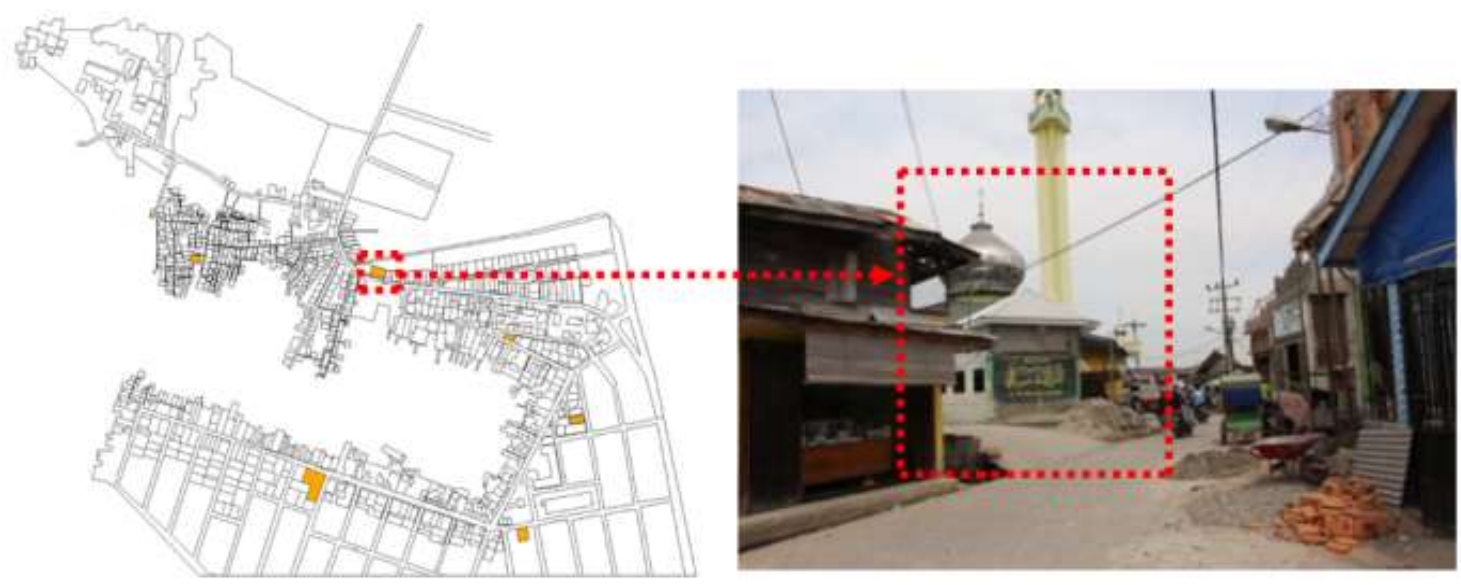

Key Map

Fig 7:- The Atmosphere of House of Worship in Fishing Village Belawan Medan

The house of worship has religious evidence in a settlement in its daily life (Wright, 1993). The theory illustrates that the religion held by the community has an important role in their lives, so the house of worship becomes one of the uses of space that is very important. 
In addition to places of worship and open space, there is a function of space as an educational facility. This facility is very important for the community especially for children who are still in school (Fig 8). The educational facilities available in this settlement are only kindergarten as well as elementary school. The unavailability of junior high school and also the high school in this area is proof that the lack of spatial use of space in the informal settlements.

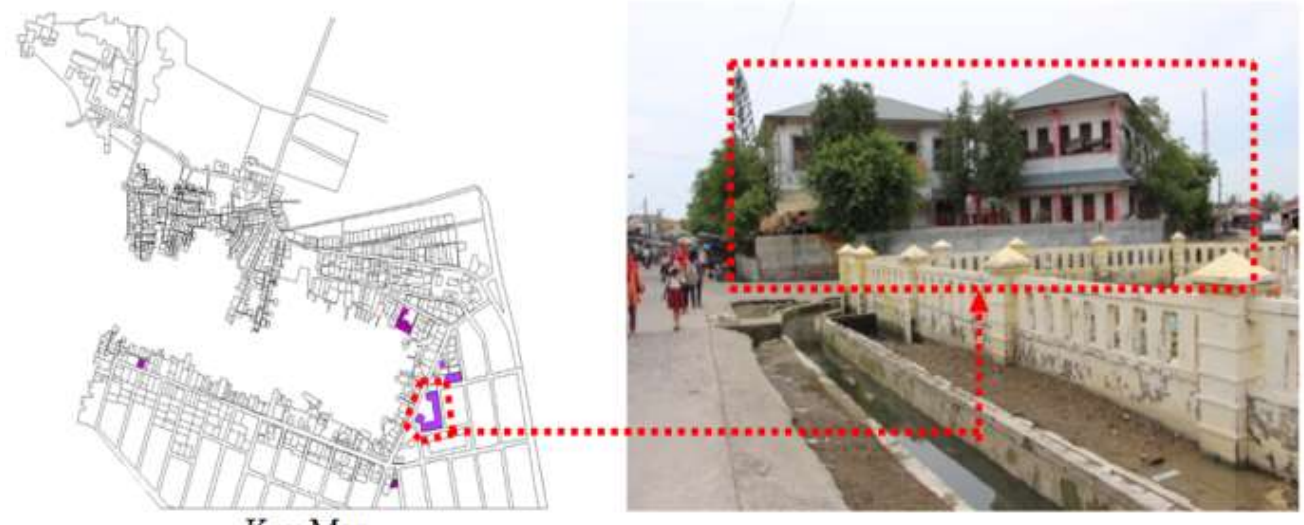

Key Map

Fig 8:- Atmosphere of Education Facilities at Fishing Village Belawan Medan

The availability of land use, road network to facilities has a purpose so that people obtain proper facilities to be able to maximize the income of the community (Hao, Sliuzas, \& Geertman, 2011). Education is very important for people's lives. The government has the idea that the higher the education of a person, of course, will affect the income of the community's economy.

Other facilities contained in this settlement is the market. A market is a place where people in buying and selling transactions. The markets in this region include traditional markets. In addition, there are some buildings in the market that have a traditional architectural style (Fig 9). Nevertheless, the market in this settlement has a fairly good positioning position. This is evidenced by the existence of a market that is in the middle of the settlement and has a strategic location that allows people to access it.

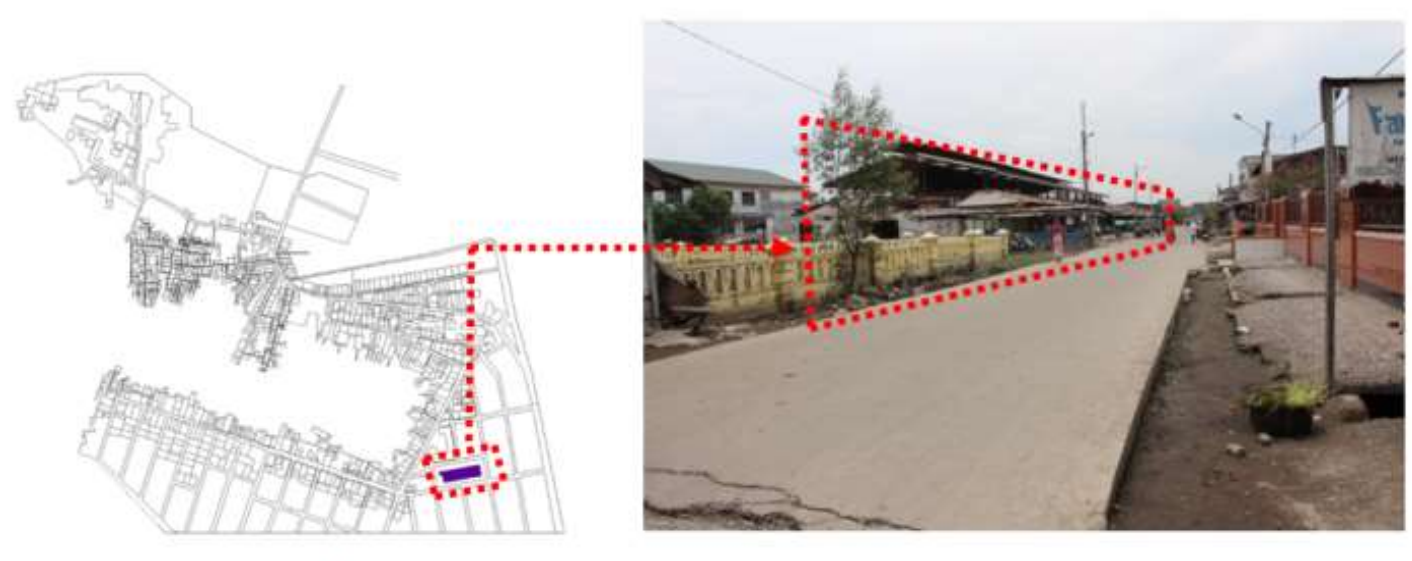

Key Map

Fig 9:- Market Atmosphere at Fishing Village Belawan Medan

The existence of these markets proves Garlake (2002) theory that the market is protected by settlements and has an impact on the community. The existence of a protected market by the settlement has a purpose so that people who come can easily access it. 


\section{Distribution of Spatial Use in Fishing Village Belawan Medan, Indonesia}

The social and economic activities of the community have an impact on the distribution of spatial use in the Fishing Village Belawan of Medan. The existence of such impacts leads to variations in space usage in the region. In addition, some locations became a crowded spot in this neighborhood and the school became one of the fairly crowded areas.

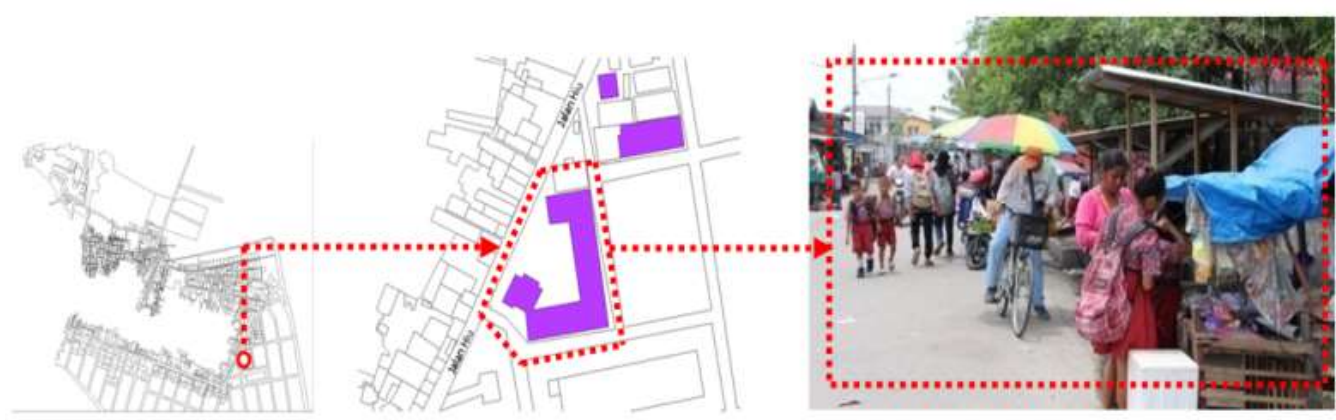

$$
\text { Key Map } \quad \text { Mapping }
$$

Fig 10:- The Ambience Atmosphere At School at Fishing Village Belawan Medan

The happiness in schools is influenced by social and economic activities. This is done by students who attend school with salespeople selling around the school (Fig 10). Social activities and buying and selling transactions are conducted simultaneously so that the school becomes a fairly crowded location. The use of land, road networks and the provision of facilities are usually provided by the government with the aim of facilitating the community (Hao et al., 2011). Schools become one of the educational facilities in this settlement. This facility is used by some people to establish a shop around the school. In addition to the community in the settlement, some sellers are migrant communities who want to sell around the school. The number of schoolchildren who buy snacks when the hours of rest or school home cause this area to be crowded. This leads indirectly to the interrelation of social and economic activities affecting the distribution of space usage.

In addition to the school, the cause of the crowd that occurred in this settlement because of the spread of stalls in these settlements. Most of the stalls in the settlement provide chairs and tables as well as facilities (Fig 11). This directly becomes a place for people to gather in the shop.

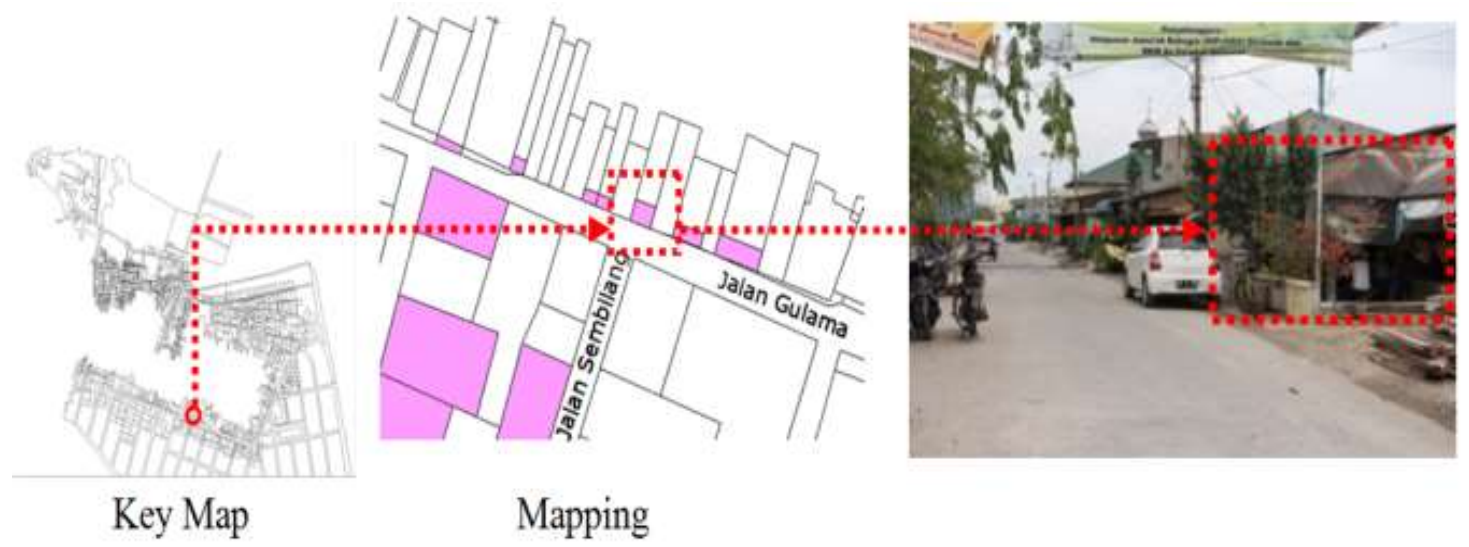

Fig 11:- Little market atmosphere in Fishing Village Belawan Medan

Humans and their communities have a connection in forming a comprehensive space because the difference needs to make space is formed completely (Rivlin, 1987). This confirms the stalls into a space-forming container so that people can easily gather at these locations. For the stall owner, the location is a place to sell and increase the owner's 
economy. However, for people who come to the stall is a container to gather. Not only gathered, people who come also do shopping activities in the shop.

\section{Conclusions:-}

In social activities, people use the home as part of their social life. A social activity that is quite routinely conducted by the people in this settlement is the implementation of tradition and also the wedding party. In carrying out the tradition and also the party, people use the house as an area for community gathering. The existence of community thinking that the house has the efficiency of time, energy to financial funds for the event. In addition, using the house as a location in carrying out social activities, a pride for the community. In addition, because of this pride, people living in settlements are reluctant to move even though these settlements are relatively informal and there is often a rising tide (floods are always occurring). People choose to stay at home when there is a rising tide. However, if the rising water flow is high enough, people will evacuate. This activity requires mutual cooperation between communities. In addition to social, economic activities undertaken by the community also use the house as its location. Most of the people in this settlement work as traders who sell by opening stalls. The terrace of the house became the home of most of the stalls in the settlement. People have thought that the terrace of the house is a fairly efficient location because of the absence of rent on the establishment of the stall and also the flexibility. This is very necessary for women because they can take care of household activities without leaving the house (work outside the home). The simultaneous social and economic activity caused an impact on the distribution of space usage. The impact of the use of space distribution causes one space / area / location / to be crowded visitors. The impact of the distribution of the use of space that looks crowded is the stall. The stalls owners in the settlement provide chairs and tables as an area to sit and even chat with the surrounding community. The little market becomes a container of interaction between people with each other. The occurrence of such interaction makes people need a place to communicate. The existence of interaction and communication made by the community cause the stall owner to provide chairs and tables as a facility. Thus, the stalls in the settlement became one of the crowded locations visited by visitors

\section{Acknowledgement:-}

The researcher would like to thank PT. Directorate of Research and Community Service (DRPM) Indonesia in the Applied Superior Research Program of Higher Education (PTUPT) 2017 which has funded this research. The researcher expects that the government can make the right decision to plan the use of land, especially a settlement that grows naturally on the coast. The reality that already existed in Fishing Village Belawan Medan is a picture of identity that gives local wisdom meaning. This research is funded by Directorate of Research and Community Service, Directorate General of Research and Technology Development, Ministry of Research, Technology and Higher Education in accordance with Applied Product Research contract of Budget year 2017 No: 73/UN5.2.3.1/PPM/KP-DRPM/2017

\section{References:-}

1. Ahmed, N., Rahman, S., Bunting, S. W., \&Brugere, C (2013) Socio-economic and ecological challenges of small-scale fishing and strategies for its sustainable management: A case study of the Old Brahmaputra River, Bangladesh. Singapore Journal of Tropical Geography, 34(1), 86-102.

2. Andah, B., Okpoko, A., Shaw, T., \& Sinclair, P. (2014). The Archaeology of Africa: food, metals and towns.

3. Boelaars, J. H. M. C. (1984). Kepribadian Indonesia modern: suatupenelitianantropologibudaya. Gramedia.

4. Crowell, M., Edelman, S., Coulton, K., \& McAfee, S. (2007). How Many People Live in Coastal Areas? 1. Journal of Coastal Research, iii-vi.

5. Fleisher, J., \& Wynne-Jones, S. (2012). Finding meaning in ancient Swahili spatial practices. African archaeological review, 29(2-3), 171-207.

6. Franco, A. D. S. (1966). Tides-Fundamentals Prediction And Analysis. International Hydrographic Office

7. Garlake, P. S. (2002). Early art and architecture of Africa. Oxford: Oxford University Press.

8. Hao, P., Sliuzas, R., \&Geertman, S. (2011). The development and redevelopment of urban villages in Shenzhen. Habitat International, 35(2), 214-224.

9. Hurskainen, P., \&Pellikka, P. (2004, October). Change detection of informal settlements using multi-temporal aerial photographs-the case of Voi, SE-Kenya. In Proceedings of the 5th African Association of Remote Sensing of the Environment conference, Nairobi, Kenya, unpaginated CD-ROM.

10. Horton, M. C. (1994). Swahili architecture, space and social structure. Architecture and order: Approaches to social space, 147-169. 
11. Jeyarajah, S., \&Santhirasegaram, S. THE INTERNATIONAL JOURNAL OF HUMANITIES \& SOCIAL STUDIES.

12. Rivlin, L. (1987). The Neighborhood, Personality Identity and Group Affiliations. In. I. Altman \& A

13. Setioko, B., Martini, T. W., \&Pandelaki, E. E. (2011). Conceptual Spatial Model of Coastal Settlement in Urbanizing Area. International Journal of Science and Research, 8(3), 60-66.

14. Wright, H. T. (1993). Trade and politics on the eastern littoral of Africa, AD 800-1300. The archaeology of Africa: Food, metals and towns, 658-670.

15. Yang, T., Li, M., \&Shen, Z. (2015). Between morphology and function: How syntactic centers of the Beijing city are defined. Journal of Urban Management, 4(2), 125-134. 